\title{
Nursing students' knowledge about pain assessment
}

\author{
Conhecimento dos acadêmicos de enfermagem sobre a avaliação da dor
}

Amanda Francielle Santos ${ }^{1}$, Rafaela Ribeiro Machado², Caíque Jordan Nunes Ribeiro ${ }^{3}$, José Marden Mendes Neto ${ }^{4}$, Maria do Carmo de Oliveira Ribeiro ${ }^{3}$, Míriam Geisa Virgens Menezes ${ }^{4}$

DOI 10.5935/2595-0118.20180062

\section{ABSTRACT}

BACKGROUND AND OBJECTIVES: The difficulty of the nursing staff in assessing pain, the low adherence to the registry of pain and the quality reported in other studies brings the need to assess the related factors and one of them can be the lack of knowledge. The objective of this study was to evaluate the knowledge of nursing students about pain assessment.

METHODS: A cross-sectional, descriptive and quantitative study, conducted in a Higher Education School in Aracaju, Brazil. The sample was composed of 169 nursing students over the last period of graduation. The data were obtained through a form that contained sociodemographic information, questions about pain assessment, and knowledge sources used.

RESULTS: The scales to assess pain in children and in adults are known by 70 and $66 \%$ of the students, respectively. They reported that pain assessment and the incorrect pain treatment may impair the clinical picture and aggravate the disease, both in the child $(17.2 \%)$ and the adult (15.4\%). The rate of correct answers about pain assessment ranged from 26.6 to $87 \%$. Most of them use articles to gain knowledge about pain (56.2\%). The fact of having already used a scale to assess the patient's pain $(\mathrm{p}=0.045)$ showed significant differences in the average of hits.

CONCLUSION: Nursing graduates are aware of the existence of scales to assess pain, but they do not have the ability to perform them. The prior use of scales promotes learning. The lack of knowledge about pain impacts on the patient's health.

Keywords: Knowledge, Nursing students, Pain assessment.
1. Universidade Federal de Sergipe, Programa de Pós-Graduaçẫo em Biologia Parasitária, Aracaju, SE, Brasil.

2. Universidade Federal do Vale de São Francisco, Programa de Pós-Graduação em Gestấo Pública Municipal, Petrolina, SA, Brasil.

3. Universidade Federal de Sergipe, Programa de Pós-Graduaçăo em Enfermagem, Aracaju, SE, Brasil.

4. Universidade Federal de Sergipe, Programa de Pós-Graduação em Fisiologia, Aracaju, SE, Brasil.

Submitted on May 06, 2018.

Accepted for publication on July 17, 2018.

Conflict of interests: none - Sponsoring sources: none.

Correspondence to:

Av. Marechal Rondon, s/n - Jd. Rosa Elze

49100-000 São Cristóvão, SE, Brasil.

E-mail: francyelly_amanda@hotmail.com

(C) Sociedade Brasileira para o Estudo da Dor

\section{RESUMO}

JUSTIFICATIVA E OBJETIVOS: A dificuldade da equipe de enfermagem em avaliar a dor, a baixa adesão ao registro de dor e a sua qualidade relatada em outros estudos, faz surgir a necessidade de avaliar os fatores relacionados, podendo ser um deles a deficiência de conhecimento. O objetivo deste estudo foi avaliar o conhecimento dos estudantes de enfermagem sobre a avaliaçáo da dor.

MÉTODOS: Estudo transversal, descritivo e quantitativo, desenvolvido em uma instituiçáo de ensino superior em Aracaju, SE, Brasil. A amostra foi composta por 169 acadêmicos de enfermagem do último período da graduação. Os dados foram obtidos por meio de formulário que continha questóes sociodemográficas, perguntas sobre a avaliação da dor e as fontes de conhecimento utilizadas.

RESULTADOS: As escalas para avaliação da dor na criança e no adulto são conhecidas por 70 e $66 \%$ dos acadêmicos, respectivamente. Eles relataram que a avaliação e o tratamento inadequado da dor podem prejudicar o quadro clínico e agravar a doença tanto na criança $(17,2 \%)$ quanto no adulto $(15,4 \%)$. $\mathrm{O}$ índice de acertos sobre a avaliação da dor variou entre 26,6 e $87 \%$. A maioria deles utiliza artigos para adquirir conhecimento sobre a dor $(56,2 \%)$. Já ter utilizado escala para avaliaçáo da dor do paciente $(\mathrm{p}=0,045)$ apresentou diferenças significativas na média de acertos.

CONCLUSÁO: Os formandos de enfermagem sabem da existência das escalas para avaliação da dor, porém não possuem habilidade para executá-las. A utilização prévia de escalas favorece o aprendizado. $\mathrm{O}$ baixo conhecimento quanto à dor repercute na saúde do paciente.

Descritores: Conhecimento, Estudantes de enfermagem, Mensuração da dor.

\section{INTRODUCTION}

Pain is a subjective experience of complex assessment and management. However, its relief is a patient right ${ }^{1}$. The painful sensation can occur due to surgeries, injuries, diseases or medical procedures, causing distress to patients and their family members. Therefore, the nurse should be knowledgeable on physiology, assessment, treatment, and impact of pain on the patient ${ }^{2}$.

The assessment of pain using scales and appropriate monitoring indicators make it possible to measure the intensity and check the effectiveness of the interventions ${ }^{3}$. Many instruments have been validated for the assessment of pain in different age groups and clinical conditions. As the unidimensional scales that are indicated to identify and measure the pain and are adopted to rapidly obtain information, as well as the multidimensional scales that are used to 
evaluate sensorial, affective and evaluative elements that are reflected in the language that reports painful experience ${ }^{4}$.

Despite pain being one of the most frequent reasons for the demand for health services, many times its relief is not reached. Despite the advances in pain analgesia, there are still obstacles related to its management, especially the assessment ${ }^{5}$.

The difficulty for the nursing staff to evaluate pain, the low adhesion to the use of pain record and its quality reported in other studies, brings out the need to evaluate related factors, and the lack of knowledge during training can be one of them.

The objective of this study was to evaluate nursing academic knowledge on pain assessment.

\section{METHODS}

This study is a cross-sectional, descriptive and quantitative, developed in a higher education private institution in October 2017, Aracaju, SE, Brazil.

All nursing students attending the last term of the course were included in the study. There were no exclusion criteria. Data collection occurred after the students being properly informed about the study and signed the Free and Informed Consent Form (FICT). The initial sample was expected to have 200 graduate students, according to the institution, but 31 of them refused to participate in the study. The sample consisted of 169 nursing graduate students. The questionnaire for data collection was divided into three parts with questions about the students' profile; questions on pain assessment in children and adults, and the sources of knowledge used by the students. This instrument was elaborated by the researchers and validated by a board composed of three examiners with experience in the field of study before the beginning of the data collection. A pilot with five participants for the final adequacy of the instrument was conducted, and the data of the pilot has been discarded.

The study followed the recommendations of Resolution $466 / 2012$ of the National Health Council and was approved by the Research Ethics Committee of the Estácio de Sergipe College (CAEE: 70838717.0.0000.8079) with opinion 2,269,667.

\section{Statistical analysis}

A descriptive univariate analysis was carried, and the categorization of the extracted data with the respective frequencies and percentages presented as tables. Inferential analysis was performed crossing the proportion of right answers on the knowledge test of pain assessment with the socioeconomic variables and sources of knowledge. The crossing between qualitative and quantitative variables was checked initially through the Shapiro-Wilk test if the proportion of right answers showed a normal distribution $(\mathrm{p}=0.000)$. Since normality was not observed, nonparametric tests were adopted for the analysis. For the crossing of variables with more than two categories, it was used the Kruskal-Wallis test, and for variables with two categories, the test was the Mann-Whitney. In all hypothesis tests conducted, the conclusion was obtained through the interpretation of the p-value. Adopting a significance level of $5 \%$ whenever the value of the calculated $\mathrm{p}$ is less than 0.05 , it is inferred that there is a relationship between the analyzed variables. The software used was $\mathrm{R}$, version 3.4.2 and the significance level adopted was 5\%.

\section{RESULTS}

The sample was composed predominantly of women (90.5\%), aged between 20 and 50 years, students of the night $(53.3 \%)$ and morning $(46.7 \%)$ periods. More than half of the respondents were not active in the labor market (61\%). Among the economically active, $71.2 \%$ worked as nurse technicians. Regarding the years of experience, the majority (18.3\%) had between 5 and 10 years, most of them $(5.33 \%)$ worked in the Urgency and Emergency Unit.

Seventy percent of the respondents had knowledge of the pain assessment scales in children, the faces pain rating scale being the most mentioned among the students (40.2\%). Other scales has also been cited, as the numeric pain rating scale $(8.3 \%)$, visual analog scale (VAS) (8.9\%), Behavioral Pain Scale (BPS) (0.6\%) and Leeds Assessment of Neuropathic Symptoms and Signs (LANSS) (2.4\%). As for how many scales are known, 61.3\% knew only one scale (Table 1 ).

In relation to the knowledge of scales to assess pain in adults, $66 \%$ of the students claimed to know, and the numeric scale was the most cited (31.4\%), and the BPS the least cited (0.6\%). It was also cited the faces scale (14.2\%), VAS (5.9\%), and LANSS (8.3\%). As for how many scales are known, $56.8 \%$ knew only one scale (Table 1).

Among the students, 96.4\% stated that an inadequate assessment of pain affects the clinical picture of adult and pediatric patients. However, about $22.7 \%$ did not specify the reason. The most cited reason for inadequate assessment of pain affecting the clinical picture was to induce the inadequate treatment and to worsen the disease in children (17.2\%) and in adults (15.4\%) (Table 1).

Regarding the students' knowledge on pain assessment, the study found that the highest percentage of hits, 147 (87\%), referred to the item: "the pain report of the child must be considered." The largest number of incorrect answers, 108 (63.9\%), was attributed to the question: "isolated body expression assessment may indicate that the child is in pain." Thus, the hit rate ranged from 26.6 to $87 \%$, and the rate of errors was between 4.7 and $63.9 \%$ (Table 2). In relation to the sources of information used by students to acquire knowledge about the methods of pain assessment, most said they seek knowledge in articles (56.2\%), followed by books (44.4\%), only the information received in class $(39.1 \%)$, internet videos-class $(33.1 \%)$ courses and training courses $(25.4 \%)$. Only $38.5 \%$ seek information on other sources. There were no differences in the average of hits with the information sources that are used by students to acquire knowledge about the methods of pain assessment (Table 3).

Sociodemographic variables, to work, have technical training in the nursing field, years of experience in nursing, in internship have noticed pain scales in the patient's record and be encouraged to use the pain assessment scales in children or adults did not show significant differences in the average hits. Only those who claimed to have already used some scale to assess patients' pain presented significant differences in the average of hits $(\mathrm{p}=0.045)$ (Table 4). 
Table 1. Knowledge of nursing students on the assessment of pain in children and in adults, Aracajú, SE, 2017

\begin{tabular}{|c|c|c|}
\hline Variables & Frequency & $\%$ \\
\hline \multicolumn{3}{|l|}{ Known scale for pain assessment in children } \\
\hline Faces pain rating scale. & 68 & 40.2 \\
\hline Visual analog scale. & 15 & 8.9 \\
\hline Numeric pain rating scale. & 14 & 8.3 \\
\hline Leeds Assessment of Neuropathic Symptoms and Signs & 4 & 2.4 \\
\hline Behavioral pain scale. & 1 & 0.6 \\
\hline Did not answer & 17 & 10,1 \\
\hline \multicolumn{3}{|c|}{ Why inadequate assessment of pain affects the clinical picture of the pediatric patient } \\
\hline Because of inappropriate treatment of pain worsening the disease. & 28 & 17.2 \\
\hline Because of inadequate diagnosis and treatment worsening the disease. & 23 & 14.1 \\
\hline By causing discomfort. & 15 & 9.2 \\
\hline By causing psychological trauma. & 3 & 1.8 \\
\hline By causing psychological suffering and inappropriate treatment. & 1 & 0.6 \\
\hline Yes, but did not specify the reason. & 37 & 22.7 \\
\hline Did not answer & 32 & 19.6 \\
\hline \multicolumn{3}{|l|}{ Known scale for pain assessment in adults } \\
\hline Numeric pain rating scale & 53 & 31.4 \\
\hline Faces pain rating scale & 24 & 14.2 \\
\hline Leeds Assessment of Neuropathic Symptoms and Signs & 14 & 8.3 \\
\hline Visual analog scale & 10 & 5.9 \\
\hline Behavioral pain scale & 1 & 0.6 \\
\hline Yes, but did not specify which. & 30 & 17.8 \\
\hline By causing changes in other vital signs. & 9 & 5.6 \\
\hline By causing psychological trauma. & 3 & 1.9 \\
\hline By inappropriate treatment of pain. & 5 & 3.1 \\
\hline By causing psychological suffering and inappropriate treatment. & 1 & 0.6 \\
\hline Yes, but did not specify the reason. & 35 & 21.6 \\
\hline Did not answer & 38 & 23.5 \\
\hline
\end{tabular}

Table 2. Knowledge test applied to nursing students on pain assessment, Aracajú, SE 2017

\begin{tabular}{|c|c|c|c|c|c|c|}
\hline & \multicolumn{2}{|c|}{ Hits } & \multicolumn{2}{|c|}{ Errors } & \multicolumn{2}{|c|}{$\mathrm{NI}$} \\
\hline & $\mathrm{n}$ & $\%$ & $\mathrm{n}$ & $\%$ & $\mathrm{n}$ & $\%$ \\
\hline There are specific pain assessment scales for newborn, children and adults. & 119 & 70.4 & 41 & 24.3 & 9 & 5.3 \\
\hline The numeric scale and faces scale can be used to assess pain in children as of six years. & 83 & 49.1 & 70 & 41.4 & 16 & 9.5 \\
\hline $\begin{array}{l}\text { The assessment of pain by the faces scale is made by attributing colors to represent the intensity, } \\
\text { the greater the intensity of the pain. }\end{array}$ & 72 & 42.6 & 81 & 47.9 & 16 & 9.5 \\
\hline The assessment by the numeric scale is made by assigning numeric values to the level of crying. & 65 & 38.5 & 85 & 50.3 & 19 & 11.2 \\
\hline The pain report of the child must be considered. & 147 & 87.0 & 8 & 4.7 & 14 & 8.3 \\
\hline $\begin{array}{l}\text { The scales to assess pain in children are a safe instrument, allowing to identify not only the presence } \\
\text { but also the intensity of pain. }\end{array}$ & 119 & 70.4 & 30 & 17.8 & 20 & 11.8 \\
\hline
\end{tabular}


Table 3. Information sources used and its comparison with the result of the student on the knowledge test, Aracajú, SE, 2017

\begin{tabular}{|c|c|c|c|c|c|c|}
\hline & Frequency & $\%$ & Mean & Standard deviation & Median & $P$ value \\
\hline \multicolumn{7}{|c|}{ Information transmitted by the teachers during class } \\
\hline No & - & - & 54.42 & 50.00 & 20.93 & 0.701 \\
\hline Yes & 66 & 39.1 & 53.52 & 50.00 & 19.98 & \\
\hline \multicolumn{7}{|l|}{ Books } \\
\hline No & - & - & 55.56 & 50.00 & 20.28 & 0.476 \\
\hline Yes & 75 & 44.4 & 52.23 & 50.00 & 20.76 & \\
\hline \multicolumn{7}{|c|}{ Scientific papers } \\
\hline No & - & - & 51.07 & 50.00 & 18.03 & 0.134 \\
\hline Yes & 95 & 56.2 & 56.32 & 62.50 & 22.01 & \\
\hline \multicolumn{7}{|c|}{ Training courses } \\
\hline No & - & - & 54.92 & 50.00 & 20.30 & 0.648 \\
\hline Yes & 43 & 25.4 & 51.52 & 50.00 & 21.14 & \\
\hline \multicolumn{7}{|c|}{ Internet video-classes } \\
\hline No & - & - & 54.36 & 50.00 & 21.07 & 0.993 \\
\hline Yes & 56 & 33.1 & 53.47 & 50.00 & 19.49 & \\
\hline
\end{tabular}

Table 4. Comparison of the proportion of hits on the knowledge test and the sociodemographic and academic variables, Aracajú, SE, 2017

\begin{tabular}{|c|c|c|c|c|}
\hline Variables & Mean & Standard deviation & Median & $p$ Value \\
\hline \multicolumn{5}{|l|}{ Gender } \\
\hline Male & 55.10 & 62.50 & 20.73 & 0.311 \\
\hline \multicolumn{5}{|c|}{ Age group (years) } \\
\hline 20 to 25 & 53.85 & 50.00 & 22.85 & 0.500 \\
\hline 36 to 40 & 55.56 & 62.50 & 14.99 & \\
\hline 41 to 50 & 59.09 & 62.50 & 20.98 & \\
\hline \multicolumn{5}{|l|}{ Working } \\
\hline No & 52.25 & 50.00 & 21.79 & 0.106 \\
\hline Yes & 54.17 & 62.50 & 17.55 & \\
\hline \multicolumn{5}{|c|}{ Experience (years) } \\
\hline Less than 5 & 56.94 & 62.50 & 14.13 & 0.629 \\
\hline 5 to 10 & 58.06 & 62.50 & 16.94 & \\
\hline 11 to 20 & 55.83 & 62.50 & 17.59 & \\
\hline Above 20 & 37.50 & 37.50 & & \\
\hline \multicolumn{5}{|c|}{ During internship, it was observed pain scales on patient's record } \\
\hline No & 53.81 & 50.00 & 20.49 & 0.285 \\
\hline Yes & 57.41 & 62.50 & 18.43 & \\
\hline \multicolumn{5}{|c|}{ Was encouraged to use pain assessment scales in children or adults } \\
\hline
\end{tabular}

Kruskal-Wallis and Mann-Whitney tests * $\mathrm{p}$-value $<0.05$. 


\section{DISCUSSION}

The knowledge of pain management is essential in the clinical nursing practice, with a direct impact on the patient's health ${ }^{1}$. That's why the ability to assess the pain is critical ${ }^{3}$.

Little more than half of the nursing students have heard of an instrument to assess pain in adults, the most cited was the numeric scale. Many of them knew some scale for pain assessment in children, the most cited was the faces scale. Other scales were also cited as BPS, VAS, and LANSS, though in a lesser extent for both. Most claimed to know just one pain assessment instrument. Pain scales for assessment in a sedated patient with communication difficulty and multi-dimensional are still little mentioned, which is a risk factor for the inadequate assessment of these patients.

The VAS was cited as an option to assess pain in children, but they can have difficulty in understanding it. Some instruments use more appropriate visual resources for this age group ${ }^{6}$. The study showed that the nursing trainees may have difficulty in choosing the most adequate scale for each age.

In the objective test of students' knowledge on pain assessment, the highest frequency of hits refers to the affirmation that the child's report of the pain must be considered. A positive fact, because the self-report is the gold standard for assessment of the patient's pain ${ }^{7}$.

The largest number of incorrect answers relates to statements that the isolated assessment of body language and cry can be considered as an indicator of the presence of pain or to determine the intensity of pain in children. Changes in facial expression, body movement and crying are still quite considered by health professionals as a parameter of pain, but they should not be used alone, because the patient may present them for other reasons such as discomfort, hunger or fear ${ }^{8}$. Moreover, even if an isolated feature confirms the presence of pain, the health professional would not be able to quantify the intensity, which is of paramount importance for the choice of the appropriate drug.

Many students erroneously consider true the statement that the assessment with a numerical scale is used by assigning numeric values to the level of the child's crying. And the same happened in the statement that the pain assessment by faces scale is accomplished by assigning colors to represent the intensity of pain. This result is inconsistent with another result of this study, which may represent that despite being the most cited scales by nursing students, they don't know how to use them, knowing them only by name.

In the numeric scale, the patient chooses a number from one to 10 to represent the intensity of their pain. These numbers represent the intensity of pain, incrementally ${ }^{9}$. The faces scale is constituted by six faces, the first is a smiling expression, that is transforming until it reaches the last face, very sad. The child can choose the one he/she most identifies with ${ }^{4}$.

The average of hits was a little more than half the total of the questions. This study corroborates a study with nursing students to assess their knowledge about pain, where it was observed that the majority failed to answer correctly less than $50 \%$ of the questions, mostly about drugs and pain assessment ${ }^{2}$. It is evidenced that most of the future nursing professionals have deficiencies in the basic knowledge of the fundamental stage of pain management.

Pain assessment is crucial, because the acute pain, if left untreated, increases the time of activation of neural pathways, extending the harmful effects such as elevation of vital signs, reduced tissue oxygenation ${ }^{10}$, impairing the sleep which may lead to exhaustion ${ }^{11}$, and is associated with risk of progression to chronic pain $^{12}$.

Most nursing students agree that inadequate pain assessment undermines the patient's clinical condition, as it compromises the diagnosis, treatment and leads to worsening of the disease. But they think that pain has similar consequences in adults and children, attributing more psychological suffering to the adult. In a study by Nascimento et al. ${ }^{13}$ it is stated that in children, the impact of pain may be even greater by the lack of ability to report the pain or by the way they perceive the painful sensation. Therefore, most of the students have an incorrect view of the impact caused by the pain in adults and children. The lack of proper understanding of pain influences and undermines its follow-up. Most students seek information about pain primarily in papers, followed by books, teachers, video-classes and training courses. However, a great number is limited to what is taught by the professor. A similar result was showed in a study conducted with nursing students of three universities of Jordan. The majority has not searched information sources on pain and reported that has never participated in courses ${ }^{14}$. Both students and nursing professionals must seek the improvement of their knowledge, as they have responsibilities in the management of pain ${ }^{15}$.

Opposing the common sense, to have the technical education or to work in the nursing field have not intervened with the level of knowledge. Perhaps this result is because this subject is of easy understanding. Therefore, the time dedicated to work does not harm the learning. But the technical training will work only if the assessment of pain is taught in the technical training of the professional or if the institution adheres to the use and provides continued education on the topic.

Students who have used a scale to assess patient's pain showed significant differences in the mean of correct answers, that is, the students who have had the experience of applying the scales have greater knowledge in the assessment of the pain. According to these outcomes, in a study conducted with nursing students in Jordan, the ones who used more the pain rating scales showed significantly greater knowledge ${ }^{15}$. Therefore, it is necessary to ally the theoretical instruction with the practical experience in the education of future health professionals.

When the pain of the hospitalized patient is properly managed, it results in shorter hospitalization, avoids aggregated comorbidity and improves the well-being of patients and their families. It is essential that health professionals master the knowledge about pain to guide the decision-making in clinical practice ${ }^{16}$.

\section{CONCLUSION}

Nursing students know about the existence of scales for pain assessment, but often do not have specific knowledge on how 
to use them or to choose the appropriate one for each type of patient. The previous use of scales promotes learning. The little knowledge of the students about pain goes beyond assessment, and it impacts the health of the patient.

\section{REFERENCES}

1. Ucuzal M, Doğan R. Emergency nurses' knowledge, attitude and clinical decision-making skills about pain. Int Emerg Nurs. 2015;23(2):75-80.

2. Gadallah MA, Hassan AM, Shargawy SA. Undergraduate nursing students' knowledge and attitude regarding pain management of children in Upper Egypt. J Nurs Educ Pract. 2017;7(6):101-8.

3. Teixeira JM, Durão MC. Monitorização da dor na pessoa em situação crítica: uma revisăo integrativa da literatura. Rev Enferm Referência. 2016;Série IV(10):135-42.

4. Sousa FA. [Pain: the fifth vital sign]. Rev Lat Am Enfermagem. 2002;10(3):446-7. Portuguese.

5. Pretorius A, Searle J, Marshall B. Barriers and enablers to emergency department nurses' management of patients' pain. Pain Manag Nurs. 2015;16(3):372-9.

6. Kanai KY, Fidelis WM. Conhecimento e percepção da equipe de enfermagem em relação à dor na criança internada. Rev Dor. 2010;11(1):20-7.

7. Jensen MP, Karoly P, Braver S. The measurement of clinical pain intensity: a compari- son of six methods. Pain. 1986;27(1):117-26.

8. Herr K. Pain assessment strategies in older patients. J Pain. 2011;12(3):S3-S13.

9. Gonçalves B, Holz AW, Lange C, Maagh SB, Pires CG, Brazil CM. Care of children in pain admitted to a pediatric emergency and urgency unit. Rev Dor. 2013;14(3):179-83.

10. Posso IP, Pires PW, Birolini D. Instituto Central do Hospital das Clínicas da Faculdade de Medicina da Universidade de São Paulo. Divisăo Clínica III. Divisăo de Anestesia. A dor como $5^{\circ}$ sinal vital. Controle da dor aguda no pós-operatório. Sáo Paulo: Cristália; 2006. 56p.

11. Silva FS, Fernandes MV, Volpato MP. Diagnósticos de enfermagem em pacientes internados pela clínica ortopédica em unidade médico-cirúrgica. Rev Gaúcha Enferm. 2008;29(4):565-72.

12. Souza RC, Garcia DM, Sanches MB, Gallo AM, Martins CP, Siqueira IL. Conhecimento da equipe de enfermagem sobre avaliação comportamental de dor em paciente crítico. Rev Gaúcha Enferm. 2013;34(3):55-63.

13. Nascimento LC, Strabelli BS, de Almeida FC, Rossato LM, Leite AM, de Lima RA. Mothers' view on late postoperative pain management by the nursing team in children after cardiac surgery. Rev Lat Am Enfermagem. 2010;18(4):709-15.

14. Al-Khawaldeh OA, Al-Hussami M, Darawad M. Knowledge and attitudes regarding pain management among Jordanian nursing students. Nurse Educ Today. 2013;33(4):339-45.

15. Lobo AJ, Martins JP. Dor: conhecimentos e atitudes dos estudantes em um ano de seguimento. Texto Contexto Enferm. 2013;22(2):311-7.

16. Ribeiro MC, Costa IN, Ribeiro CJ, Nunes MS, Santos B, Santana JM. Knowledge of health professionals about pain and analgesia. Rev Dor. 2015;16(3):204-9. 